\title{
波形の相似な地震の発生と二，三の問題
}

\author{
東北大学理学部地球物理学教室 浜 口 博 之 \\ 東北大学理学部青葉山地震観測所 長 谷川昭 \\ (昭和 50 年 2 月 13 日受理)
}

\section{Recurrent Occurrence of the Earthquakes with Similar Wave Forms and Its Related Problems}

\author{
Hiroyuki HaMaguchI \\ Geophysical Institute, Faculty of Science, Tôhoku University \\ Akira HASEGAWA \\ Aobayama Seismological Observatory, Faculty of Science, Tôhoku University \\ (Received February 13, 1975)
}

In the course of examining the wide dynamic range records of the aftershocks of the Tokachi-oki Earthquake of 1968, the seventy two shocks having similar wave forms out of about 50,000 aftershocks were found by means of a simple but systematic data sorting. High correlations in $\mathrm{P}$ and later phases are clear not only among the events of the same order of magnitude but also among the events with considerably different magnitudes $(M=1 \sim 4.6)$. The recurrent occurrence of such events can be traced for the length of about 50 days, which is much longer duration compared with so-called twin or triple shocks reported so far. The activity is, as a whole, a swarm type; however, it is composed of several foreshock-main shock-aftershock sequences. The determination of hypocenters for the several large shocks shows that the events are closely distributed in space within the range of $5 \mathrm{~km}$, which suggests that they have common spatial and dynamical characters. Hereby, the group of earthquakes having a similar wave character can be called an Earthquake Family, which may be the most basic unit of sequence of shocks.

The nature of this family is characterized by a small $b$-value of 0.43 (total number $=$ 68) in the Gutenberg-Richter's formula: this result is in qualitative harmony with Mogi's explanation on $b$-value. The variations of $\mathrm{P}$ wave spectral amplitude ratio with magnitude are compared with the $\omega^{2}$ - and $\omega^{3}$-theoretical source models and the $\omega^{2}$-model agrees well with the observed data in the frequency range between 4.6 and $16.2 \mathrm{~Hz}$. The average $Q_{\alpha}$ in the crust is estimated to be 400 from the frequency dependence of the difference between the observed and theoretical amplitude ratio.

\section{§1.はじめに}

1968 年 5 月 16 日の十勝沖地震 $\left(M_{\mathrm{JMA}}=7.8\right)$ の余震を岩手県軽米町で高感度・広 dynamic 
range の測定器で観測をおこない 5 万個を越す余震を観測することができた。これらの地震記 録の磁気テープからの再生時やデータ験測の際, 地震記象の pattern が互いに良く似て抢り,

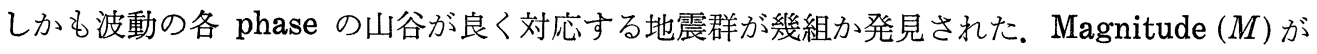
同じ位の場合にはこれらの地震は細部にいたるまでほとんど完全に一致した pattern を示し 「相似な地震」と呼んでもさしつかえない，松沢（1933）の本にはこのような相似な地震発生 の例として 1928 年 5 月のスイスでの記録が 2 個示されたあと次のように記述されている. 「このことは一見極めて平凡なる事柄のやらであるが随分深長なる意味を蔵して居るものであ る. 第一に殆んど同一地点に起つた地震を同一場所で観測したのであるから径路の条件は全く 同一である。したがつて震源に於ける発振が全く相似に行はれたと見るほかは無いのである. 而して大きさが 2 倍も違ふに拘はらず全く相似な振動が発生し得ると云ふことも随分興味深い 事柄である」.

このような例は古くは OMORI (1905，1919) の論文中に，またその後は BERCKHEMER (1962)， Miyamura et al. (1965), Stauder and Ryall (1967), McEvilly and CaSaday (1967), OIKE (1969), TSUJIURA (1973) 等の論文中にその記象例を見ることができる. 地震とは少し 異なるが月震の場合には Thermal Moonquake と呼ばれているものが各大陰月のほぼ同じ時 刻に，ほぼ同じ大きさの相い似た波形をもつて現われることが知られている [DUENNEBIER and SutToN (1974)].

これまでの例から見るとこのような地震の発見は互の地震の記録振幅のほぼ等しい場合であ り, 験測者が視覚と記憶にたよつて偶然に発見された場合が多いように推察される. MIYAMURA et al. (1965) は和歌山地方の群発地震で見出された二つないし三つの相似な地震からな る群を Twin または Triple shocks と呼び，また STAUDER and RYALL (1967) はネバダ での発見例に Familiar Earthquakes なる名称を冠した。 しかしいずれも地震数が少いため 相似な地震群の性質を組識的に調べるまでに至らなかつた。

我々は約 50,000 個におよぶ余震のデータから以下に述べるような簡単な操作でこれまでに 見出された数個よりなる相似な地震群例よりもはるかに数の多い 72 個におよぶ相似地震群を 始めとしてこれよりも数の少い同様な群を数例見出すことが出来た。これ等の地震は高感度・ 広 dynamic range の観測方式のため $M$ の広い範囲にわたつて波形歪みなしに磁気テープに 記録されていることがこれまでの報告例と較べて特徵的な点である。ここでは上記 72 個より なる最も活動の高い地震群について波形を示すと共に, その発生様式, スペクトル等について 述べる. 
Table 1. Complete list of the earthquakes with similar wave forms (the earthquake family). The blanks in $S-P$ column are due to the overlapping by the next event.

\begin{tabular}{|c|c|c|c|c|c|c|c|c|c|c|c|c|c|}
\hline & $\mathrm{D}$ & $\mathrm{H}$ & $\mathrm{M}$ & $\mathrm{S}$ & $S-P$ & $M$ & & $\mathrm{D}$ & $\mathrm{H}$ & $\mathrm{M}$ & $\mathrm{S}$ & $S-P$ & $M$ \\
\hline \multirow[t]{23}{*}{ MAY } & 19 & 01 & 39 & 22 & 8.27 & 1.2 & \multirow[t]{30}{*}{ JUN. } & 6 & 04 & 55 & 21 & 8.14 & 0.7 \\
\hline & 19 & 01 & 40 & 28 & 7.77 & 1.3 & & 6 & 12 & 57 & 34 & 8.14 & 3.0 \\
\hline & 20 & 00 & 43 & 37 & 8.07 & 1.1 & & 6 & 12 & 59 & 49 & 8.11 & 3.3 \\
\hline & 21 & 03 & 45 & 42 & 8.32 & 1.4 & & 7 & 03 & 57 & 17 & 8.18 & 1.2 \\
\hline & 21 & 08 & 22 & 33 & 7.69 & 3.1 & & 7 & 04 & 40 & 12 & & 1.0 \\
\hline & 22 & 12 & 52 & 36 & 7.94 & 0.9 & & 7 & 04 & 40 & 18 & 8.20 & 2.6 \\
\hline & 22 & 13 & 39 & 52 & 7.97 & 1.6 & & 7 & 16 & 51 & 26 & 8.04 & 0.2 \\
\hline & 25 & 08 & 56 & 00 & 8.15 & 2.6 & & 8 & 08 & 32 & 05 & 8.04 & 1.1 \\
\hline & 25 & 08 & 57 & 40 & 8.11 & 0.9 & & 9 & 17 & 42 & 46 & 8.04 & 0.7 \\
\hline & 25 & 21 & 12 & 56 & 8.09 & 1.6 & & 10 & 11 & 32 & 40 & 8.08 & 0.8 \\
\hline & 26 & 13 & 08 & 12 & 8.32 & 0.8 & & 12 & 06 & 30 & 10 & 8.00 & 0.6 \\
\hline & 26 & 13 & 52 & 10 & 8.02 & 2.4 & & 14 & 04 & 31 & 28 & 8.08 & 4.6 \\
\hline & 26 & 13 & 55 & 00 & 8.11 & 0.1 & & 14 & 11 & 38 & 56 & 8.03 & 4.4 \\
\hline & 27 & 17 & 04 & 55 & 8.30 & 0.7 & & 14 & 11 & 39 & 57 & 8.13 & 3.4 \\
\hline & 28 & 04 & 06 & 44 & 8.10 & 2.3 & & 14 & 11 & 44 & 15 & 7.78 & 1.3 \\
\hline & 28 & 04 & 08 & 02 & 8.10 & 3.1 & & 14 & 11 & 56 & 44 & 8.03 & 1.2 \\
\hline & 28 & 04 & 59 & 54 & 8.06 & 0.8 & & 14 & 13 & 35 & 31 & 8.08 & 1.1 \\
\hline & 28 & 08 & 42 & 43 & 8.15 & 1.6 & & 14 & 16 & 55 & 11 & 8.11 & 2.0 \\
\hline & 28 & 08 & 43 & 33 & 7.97 & 1.0 & & 14 & 17 & 13 & 29 & 8.10 & 1.2 \\
\hline & 28 & 11 & 50 & 31 & 8.12 & 0.9 & & 14 & 17 & 18 & 44 & 8.11 & 0.8 \\
\hline & 28 & 17 & 40 & 32 & 8.15 & 2.2 & & 14 & 17 & 32 & 11 & 7.78 & 0.7 \\
\hline & 29 & 17 & 33 & 48 & 7.99 & 1.2 & & 14 & 19 & 33 & 48 & 8.11 & 0.9 \\
\hline & 30 & 04 & 59 & 37 & 8.10 & 2.5 & & 14 & 22 & 39 & 37 & 8.02 & 0.7 \\
\hline \multirow[t]{13}{*}{ JUN. } & 2 & 07 & 05 & 58 & 8.09 & 1.4 & & 15 & 02 & 06 & 11 & 8.00 & 1.9 \\
\hline & 2 & 07 & 05 & 58 & 8.08 & 1.9 & & 15 & 03 & 09 & 00 & 7.97 & 3.4 \\
\hline & 2 & 08 & 42 & 04 & 8.13 & 3.1 & & 17 & 15 & 07 & 12 & 8.06 & 2.1 \\
\hline & 2 & 09 & 03 & 15 & 8.05 & 0.8 & & 19 & 04 & 14 & 34 & 8.05 & 1.4 \\
\hline & 2 & 10 & 11 & 12 & 8.07 & 1.1 & & 24 & 19 & 54 & 04 & & 1.0 \\
\hline & 2 & 16 & 14 & 17 & 8.31 & 0.7 & & 26 & 13 & 06 & 30 & 8.09 & 2.3 \\
\hline & 2 & 16 & 18 & 02 & 7.90 & 1.4 & & 26 & 13 & 20 & 36 & 8.04 & 2.1 \\
\hline & 2 & 16 & 20 & 46 & 8.08 & 1.9 & \multirow[t]{6}{*}{ JUL. } & 3 & 19 & 36 & 22 & 7.78 & 1.6 \\
\hline & 2 & 19 & 56 & 40 & 7.74 & 0.8 & & 4 & 15 & 02 & 49 & 7.90 & 1.0 \\
\hline & 2 & 22 & 41 & 57 & 8.07 & 0.6 & & 7 & 07 & 24 & 22 & 8.11 & 3.7 \\
\hline & 3 & 02 & 57 & 58 & 7.83 & 0.7 & & 7 & 23 & 44 & 25 & 8.12 & 0.8 \\
\hline & 5 & 14 & 34 & 17 & 8.21 & 0.2 & & 8 & 18 & 46 & 28 & 7.81 & 0.2 \\
\hline & 5 & 17 & 45 & 29 & 7.90 & 0.6 & & 9 & 09 & 09 & 03 & 8.05 & 1.2 \\
\hline
\end{tabular}

\section{§2. 観測及びデータ処理}

余震の臨時観測は岩手県軽米町增子内の廃坑 $\left(40^{\circ} 18.9^{\prime} \mathrm{N}, 141^{\circ} 32.1^{\prime} \mathrm{E}\right)$ を利用して本震発 


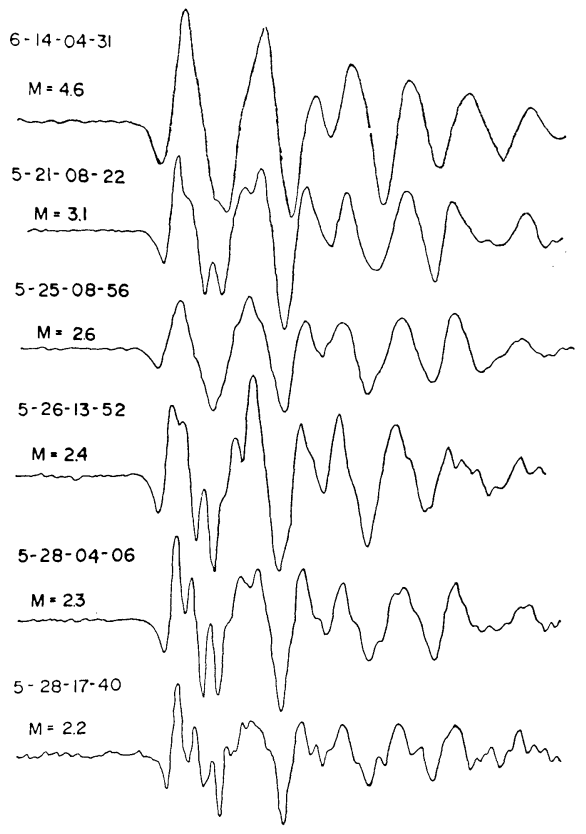

生後約 50 時間あとより約 3 ケ月間継続され た。

この観測では $M$ の広い範囲を振り切らず に記録するため上下動地震計 $\left(f_{0}=2.5 \mathrm{~Hz}\right)$ からの出力は利得の異なる増幅器を通じて, 高, 中, 低倍率の 3 段階に分けて磁気テー プ・レコーダに記録された。観測方式および 周波数特性等の詳細は前報 [HAMAGUCHI and Hasegawa (1970), Research Group FOR AFTERSHOCKS (1971)] に報告してある のでここでは省略する.

多数の余震の中より相似な地震を系統的に ピックアップする作業を従来のように験測者 の記憶に頼つて行らことは到底不可能なこと であろう．またすべての地震について相互相

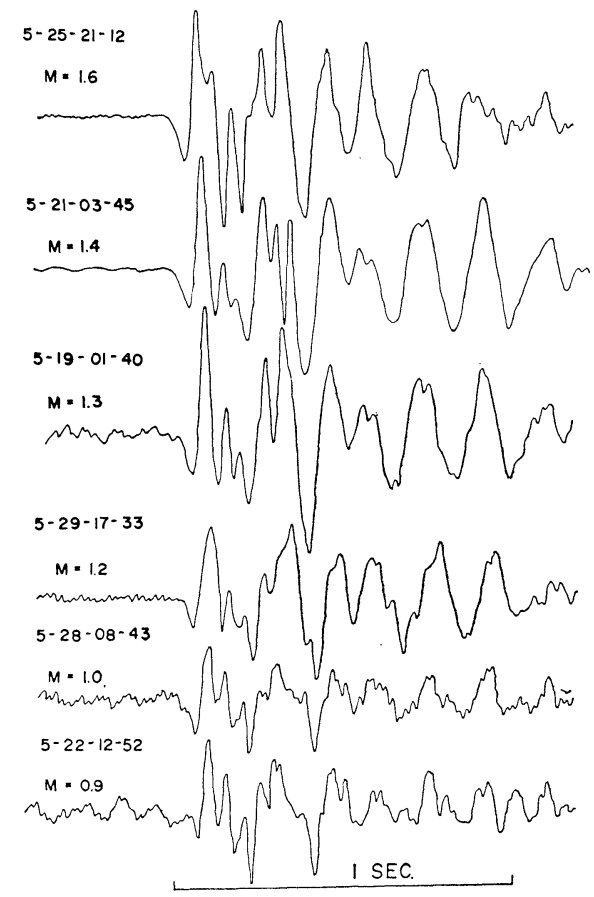

関係数を計算することもこれまた不可能に近 い.そこで次のような簡便な手順で作業を進 めた。 まず験震表の内容として $\mathrm{P}$ 波着震時刻, $S-P$ 時間, 最大振幅值, チャンネル番号, 初 動極性と共に記象の pattern を7段階にわ けて各々の地震にどれかの pattern indexを 附す。この pattern 区分をあまり多くの段 階に細分してもそれ程意味がない。記録の pattern 認識・分類も験測者の感覚的要素が

Fig. 1. Example of seismograms in magnitude order for the $\mathrm{P}$ wave parts of the earthquake family; the amplitude is adjusted so as to have about the same amplitude. Peaks and troughs following $P$ onset have high correlation even between the shocks having considerably different magnitude. The numerals attached in each trace indicate month, day, hour and minute, respectively. 
多分に入ることおよびこまかく見ればほとんど無限の pattern が存在することを考えると震 度階の分類と同様に 7 10 段階程度で止めるべきであろう。

基礎データがカード化されると分類の第一段階としては $S-P$ 時間と pattern index とで制 限を加えて同属の地震を拾い出す，但しこの際の制限は拾い落しを避けるためある程度ゆるく しておく必要がある. 次に紙送り速度 $5 \mathrm{~mm} / \mathrm{sec}$ の再生記録を見て対象外の地震と思われるも のをふるい落す．残つたものについてはより高速度（今回は $140 \mathrm{~mm} / \mathrm{sec}$ ) の再生記録を作り 更にチェックする. 広い dynamic range の故に $M$ が異なつても振幅が飽和することなく記 録上で目による相関をとることは容易である，以上の手順を慎重におこない今回の 72 個の相 似な地震群を見出した。 このリストは Table 1 に示されている，表中の $M$ は村松 (1964, 1966) の方法によつて 1 点より求めたものである. この方法で求めた $M$ を気象庁発表の $M_{\text {JMA }}$ と対応する全余震について比較すると $M=M_{\text {JMA }}+0.28$ (S. D. $\left.=0.47,3.5<M_{\text {JMA }}<7.2\right)$ とな る.

\section{§3. 相似な波形}

Fig. 1 の記録例は $\mathrm{P}$ 波初動 1.6 秒間の部分を記録上の振幅がほぼ同じ大きさになるよら再 生利得を調整し， $M$ の大きさの順に並べたものである．各記録にはそれぞれの地震の着震時刻 （月一日一時一分）と $M$ が付記されている。な抗この記録例としてとりあげた多くのものが 初期の地震であるのは 1968 年 5 月 30 日を境にしてレコーダーの記録速度を $17 / 8 \mathrm{inch} / \mathrm{sec}$ より $15 / 16 \mathrm{inch} / \mathrm{sec}$ に変更したので周波数特性に多少の変化があるためである.

この Fig. 1 より $M$ が小さくなるにつれて，高周波成分が卓越してくること，それにもか かわらず波の各相の山谷の対応は非常に良いことが一見して理解されるであろう．但し注意し て見ると初動から第 2 のピークまでは $M$ の減少とともに高周波成分の成長が顕著であるのに 較べて, 第 2 ピーク以後 0.8 秒間の波については $M$ が 1.2 まで $M$ による変化はほとんど 無いといつて良い. 従つてこの境界はほぼ第 2 のピーク近傍で初動からは約 0.3 秒の位置に ある. $M$ が 1.2 以下になると第 2 ピーク以後の波は急激に減衰しているょうに見える。 また $\mathrm{P}$ 波初動の見掛けの半周期は $M=4.6$ で 0.07 秒から最小の $M=0.9$ で 0.03 秒まで減少して いる.このように初動直後の波の周期は $M$ によつて異なるが全体として相関には影響しない。

次に Fig. 2 には $M$ が同じ地震であれば初動から後続波までの各相の対応がどの程度ある かを示す例として $\mathrm{P}$ 波部分と $\mathrm{S}$ 波部分を示した。 三本のトレースは $M$ が $1.2,1.4,1.2$ の 三つの地震を重ね合せたものである。一見してP波部分の対応は見事であることが理解されよ う。また一方 $\mathrm{S}$ 波の部分は $\mathrm{P}$ 波に較べると対応はやや劣るがやはり顕著である. 地震発生の日 

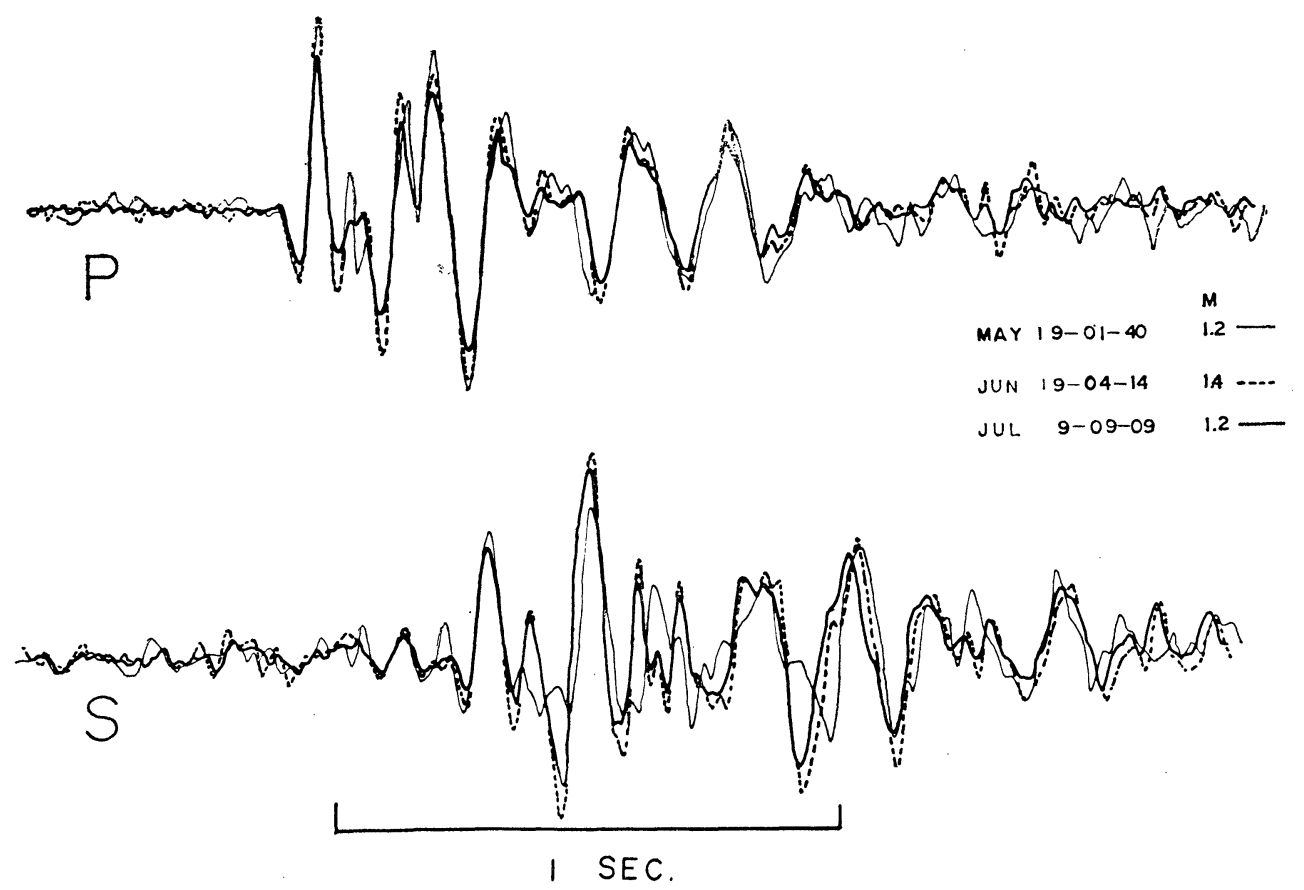

Fig. 2. Superposition of three truncate seismograms of $\mathrm{P}$ and $\mathrm{S}$ parts. Three shocks have identical magnitude. The maximum time interval of about 50 days is worthly of note.

時はこの 3 個の間で最大 50 日間離れているにもかかわらず波形の羑異が見られない事に注目 していただきたい。

このよらに速度振幅において見掛け周波数で $3 \sim 10 \mathrm{~Hz}$ 程度の波動の微細構造までを考えて もな呩かつ波動の再現性をもつ地震が多数存在しうるという今回の事実は地震の発生の, 少な くともその主要部分の機構そのものは空間的時間的に非常に単純なものであることを強く示唆 している.

\section{§4. 震 源}

松沢（1933）の言うょうに相似な地震は殆んぞ同一震源からのものと考劣て良いだろうか. Table 1 にあげた地震の内 6 月 14 日の $M=4.6$ と 4.4 については JMA の報告がある が震央は互に約 $14 \mathrm{~km}$ 離れている (Table 2)。 そこで比較的大きい地震について震源決定を 試みた。解析に使用したデータは今回の軽米観測点の他に上杵白, 恵山 (北海道大学), 石巻, 宮古, 大船渡, 八戸, 盛岡 (JMA) および青葉山, 本荘, 二ッ井 (東北大学) の各観測点の原記 録から直接読取るかあるいは読取り原簿または発行のブレティンから採用したものである。震 
Table 2. List of hypocenters for some large shocks. Nos. 8 and 9 are from JMA bulletin.

\begin{tabular}{|c|c|c|c|c|c|}
\hline No. & $\begin{array}{c}\text { Date and Time (JST) } \\
\text { H M S }\end{array}$ & $\begin{array}{l}\text { Lat. }(\mathrm{N}) \\
\text { Deg. }\end{array}$ & $\begin{array}{l}\text { Long. (E) } \\
\text { Deg. }\end{array}$ & $\begin{array}{l}\text { Depth } \\
\mathrm{km}\end{array}$ & Mag. \\
\hline 1 & May $2108-22-20.6 \pm 0.7$ & $40.33 \pm 0.02$ & $142.33 \pm 0.04$ & $12 \pm 5$ & 3.1 \\
\hline 2 & May $2613-51-56.7 \pm 1.8$ & $40.39 \pm 0.20$ & $142.33 \pm 0.12$ & $19 \pm 11$ & 2.4 \\
\hline 3 & May $28 \quad 04-06-32.5 \pm 1.1$ & $40.24 \pm 0.04$ & $142.23 \pm 0.06$ & $10 \pm 8$ & 2.3 \\
\hline 4 & May $2804-07-50.5 \pm 1.3$ & $40.30 \pm 0.06$ & $142.23 \pm 0.08$ & $17 \pm 7$ & 3.1 \\
\hline 5 & Jun $\quad 0208-41-50.4 \pm 0.9$ & $40.30 \pm 0.04$ & $142.35 \pm 0.05$ & $11 \pm 5$ & 3.1 \\
\hline 6 & Jun $\quad 0612-57-22.6 \pm 2.2$ & $40.28 \pm 0.11$ & $142.22 \pm 0.13$ & $15 \pm 11$ & 3.0 \\
\hline 7 & Jun $\quad 06 \quad 12-59-37.2 \pm 1.3$ & $40.27 \pm 0.06$ & $142.21 \pm 0.08$ & $17 \pm 7$ & 3.3 \\
\hline 8 & Jun $1404-31-13.1 \pm 0.4$ & $40.40 \pm 0.02$ & $142.30 \pm 0.03$ & 40 & 4.6 \\
\hline 9 & Jun $14 \quad 11-38-43.5 \pm 0.8$ & $40.38 \pm 0.03$ & $142.10 \pm 0.07$ & 0 & 4.3 \\
\hline
\end{tabular}

源決定には AKI (1965) の方法を使用 しまた速度構造もまた AKI のもの を使用した。計算にあたつては軽米の $\mathrm{P}$ および $\mathrm{S}$ の読取值にそれぞれ $1,1 / 2$ の，その他の観測点ではそれぞれ $1 / 2$, $1 / 4$ の重みをつけ，上記観測点で 6 点 以上のデータのあるものについて決定 を試みた。この結果 Table 2 とあげた 7 個の地震について震源が求まつた。 上述の JMA で震源の求まつた 2 個の 例についても計算したが逐次近似で収 束せず解が求まらなかつた。従つてこ

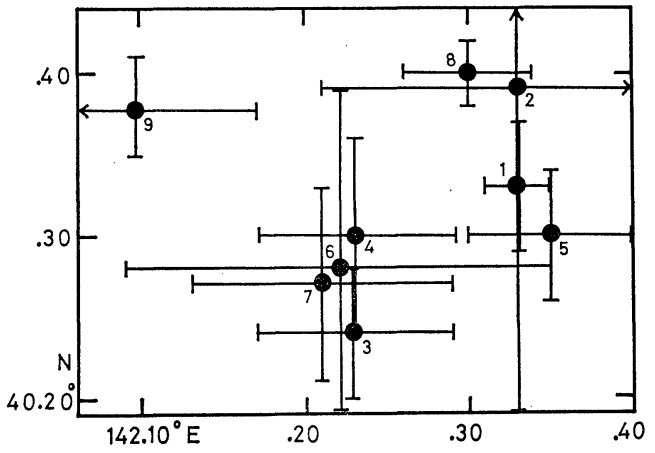

Fig. 3. The epicentral distribution of some large shocks. The bar indicates the standard deviation.

Data of Nos. 8 and 9 are taken from the Seismological Bulletin of JMA. Identification number is referred to Table 2 .

れ等の震源情報と JMA の結果を Table 2 飞並記してある.

観測点が陸側に一方的に分布している制約や定常観測点の刻時分解能などの精度を考慮する と Fig. 3 に示される Nos. 1 7 の震央はほぼ同一であると解釈せざるを得ない. 震央近傍 に観測点がないので深さの精度は悪いため今回は考慮外とする，従つて数 $\mathrm{km}$ の巾を認める ならばこれらの地震は同一震源の可能性が強い. No. 8 の JMA の震央は Nos. $1 \sim 7$ と非常 に近く有意の差はない. No. 9 の震央は Nos. 1〜8 と有意にはずれているように見える. 波 形の相似性も少し劣る.

各々の地震の大きさに対応する地震体積あるいは断層の大ささを考意し, また上述の震源精 度扣よび $S-P$ 時間の最大差が 0.63 秒であることを加味するとここにあげた相似の地震はほ 

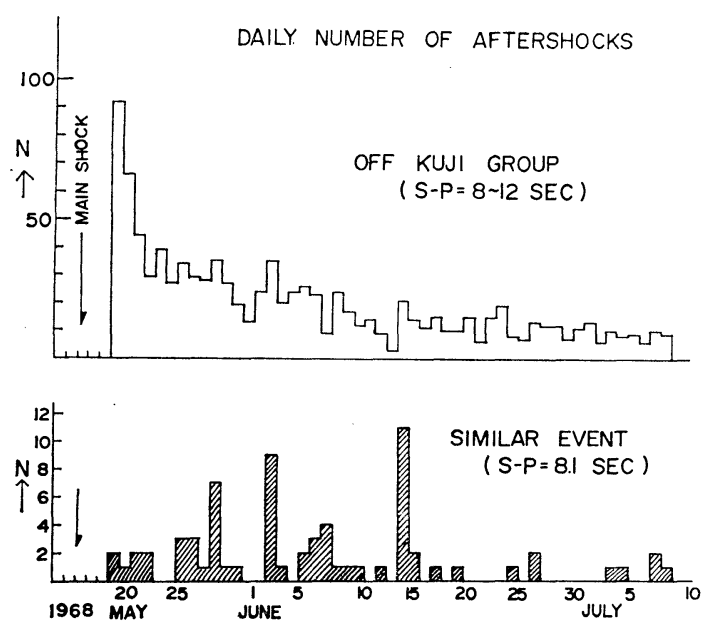

Fig. 4. Daily number of the aftershocks with $S-P$ times between 8 and 12 seconds (upper) and that of the earthquake family (lower). The number of the aftershocks decreases normally with time, but the number of events in the family does not decrease with time but rather intermittently increase.
ぼ同一の場所（少なくても $\pm 5 \mathrm{~km}$ 以

内）を共通部分として共有する形で発

生したものと結論されよう。

\section{§5. 地震活動の様式}

前節までに述べたように相似な地震 群は殆んぞ同じ場所で起こりまた同一 の発震機構をもつているものと考えて よい. Fig. 4 にはこの 地震群の日別 頻度分布とこの群の近傍の $S-P$ 時間 が 8 12 秒までの余震活動（以下久慈 沖余震群と呼ぶ)を同時に示した。 た Fig. 5 には日別積算頻度分布を示

す. 久慈沖余震活動は双曲線に従つて 減衰 $(p=0.8)$ する正常な余震活動を 示しているが，相似な地震群の活動は

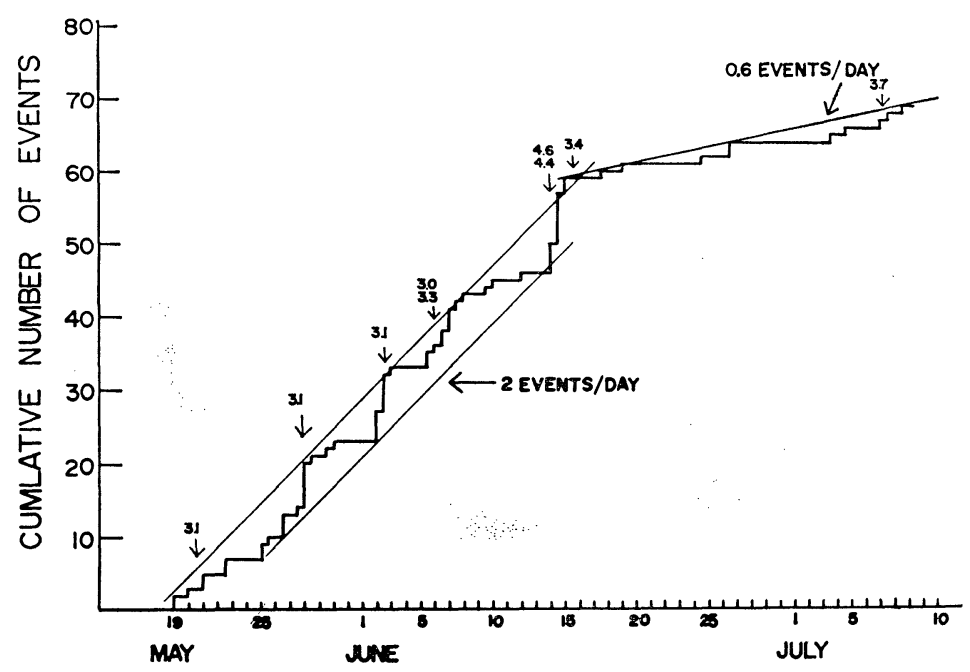

Fig. 5. Cummulative frequency of the earthquake family. Abrupt decrease in number after the occurrence of the biggest shock $(M=4.6)$ is noted. 
典型的な群発型の発生様式を示している. 長期的に見ればこの群の地震は 1 日あたり平均 2 個 (6 月 14 日まで) とかなり一様な発生を示していることがわかるが，観測期間中の 最大の地 震 (6 月 14 日, No. 8) の発生後はその活動は急激におとろえ一日あたり 0.6 個の割合に減 少した.

UTSU (1970) は MOGI (1963) の提唱した三つの地震発生型式をさらに細分し基本的には 12 個の型式を考えた。この分類に従えばこの相似な地震群は 1-C 型の群発活動に対応する。乙 かし Table 1 に示したリストを細かく検討するとこの群の最大のものである 6 月 14 日の No. 8 に続く余震活動，あるいは 5 月 28 日の No. 4 や 6 月 2 日の No. 5 を本震とする 前震一余震活動, さらには 5 月 26 日の No. 2 を本震とし 1 個の前震と 1 個の余震を持つ活 動を指摘することが出来よう。しかし最後のような例に前震，余震の名称を用いてよいか明か ではない，余震の余震といら概念はその観測例もあり一般に受け入れやすいが，余震の前震な るものの存在はその例が稀れである，以上の一見不自然なまた混乱した記述は前震，本震，余 震や群発地震の言葉の定義のあいまいさに起因する.

ここでは地震を前震, 余震等と分類する従来の立場とは別に地震の集合には基本的に Earthquake Family* という単位が存在するのではないかと言うことを提唱したい. もちろんこの 発想は相似な地震の存在という観測事実からの帰納的なものである。この Earthquake family の定義としてはある観測点で観測される波形が相似であるぐらい互の地震が空間的また力学的 な共通部分を共有する地震群としておこう。時間的な前後関係や規模の大小などの制約を一切 必要としない。

これまでの地震統計では地震を余震とか群発地震などの集合としてのみ取扱い個々の地震の 相互関係を重要視しない立場にあつた。この Earthquake family は明らかに震源での物理的 性質が同じな母集団からの標本であり単なる時系列的な重ね合せで得られるこれまでの分類に よる集合で失なわれるであろら情報が失なわれないで済むものと考える。

この Earthquake family はその中の大きい地震の発生によつて同一 family を励起するば かりでなく異なる family を誘発する能力をもち且つまたある条件のもとでは family が減じ る場合の可能性も十分に考えられよう。これまでの twin shocks や familiar earthquakes と呼ばれたものはこの Earthquake family の構成数が高々数個の場合に対応すると解釈され る.

この Earthquake family といら概念は定義のとらり空間的, 力学的な共有部分の存在にそ の特性がありまた従来の分類は時間的, 規模的な特性に重点があり両者の分類は併立して存在

*「同族地震」ではやや奇異な感じをま妨がれないのでここでは英文名称のままとする. 


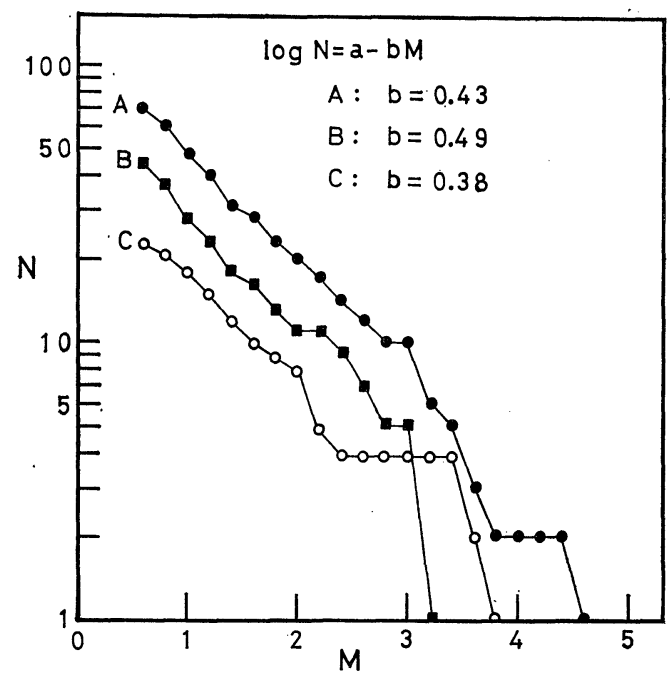

Fig. 6. Cummulative frequency of earthquakes versus magnitude. $\mathrm{A}, \mathrm{B}$ and $\mathrm{C}$ correspond to the earthquake family (all shocks), foreshocks (before the occurrence of No. 8 in Table 2) and aftershocks, respectively. Small $b$ values are to be noted.
し得る。この地震群は基本的には群発 型であるが 6 月 14 日の最大地震 (No. $8 ， M=4.6)$ を本震と考えそれ以前の ものを前震, それ以後のものを余震と 見ることも可能である. Earthquake family としての全体および前震と余 震の Gutenberg-Richter の頻度分布 を調べてみた (Fig. 6)。最尤法で求 めた $b$ 值はそれぞれ $0.43,0.49,0.38$ といずれも非常に小さい，前震と余震 の $b$ 值にも差は認められない. $M$ が 0.9 以上のものは高倍率のチャンネル で記録振幅が $5 \mathrm{~mm}_{\mathrm{P}-\mathrm{P}}$ を越えるもの であり読み落しやデータソーティング の際のもれに依るものとは考穴難い. 従つてこの Earthquake family の 0.43 という $b$ 值はこの群の固有の值であると解釈される.なおこの family について石本・ 飯田の $m$ を最尤法で求めると $m=1.43$ となり $m=b+1$ の関係 [SUZUKI $(1953,1959)$ ] が良く成立している。このことは $m$ と $b$ の関係を求める際に仮定したいくつかの条件をこ の family は十分に満足しているからである.

UTSU (1970) は $b$ 值の異常に小さい值の説明として本震 (trigger event) とそれに伴う地 震は異なる母集団からの抽出であろうとの考えに基づいて例えば 1-C 型の地震群のもつ Magnitude 頻度分布は 1-A 型の重ね合せであると解釈し小さい $b$ 值は見掛上のものである 可能性があることを指摘し，この立場から SUYEHIRO et al. (1964), SUYEHIRO (1969) の 結果や東北日本太平洋の群発地震の $b$ 值 [UTSU (1969)] を説明しようと試みた。この考えに 従つて今回の $b$ 值を検討してみよう. Table 1 のリストや Fig. 3 より判断して $M \geq 3$ の地 震を trigger events と考えてみる.これらの trigger events を除いたものについて UTSU (1971) の Table 19 を使つて $b$ 值を求めると Earthquake family 全体, 前震, 余震でそれ ぞれ $0.50,0.53,0.57$ となり trigger events を含めた場合と同様にいずれもまだこれまで に知られている $b$ 值に比較すると小さい值である. しかしここで用いた $M \geq 3$ の地震を trigger events であるとして除外することは Earthquake family が同一母集団に属すると 
いう立場と矛盾する。この矛盾を避け るためには trigger events を導入しな いかまたは trigger events は異なる 母集団に属するとの考㝋を放棄しなけ ればならない。これまでに述べた観測 事実より後者の方がより自然なように 思觉る。こでは $b$ 值の小さい值は見 掛け上のものでなく trigger eventsを 同一母集団にもつような Earthquake family に個有の值であると解釈する. これまで報告されている $b$ 值の小さい 前震や群発地震についてその 構成が Earthquake family であるか否かの 検討は興味ある問題として将来に残さ れる。

$b$ 值の物理的意味を解釈するために

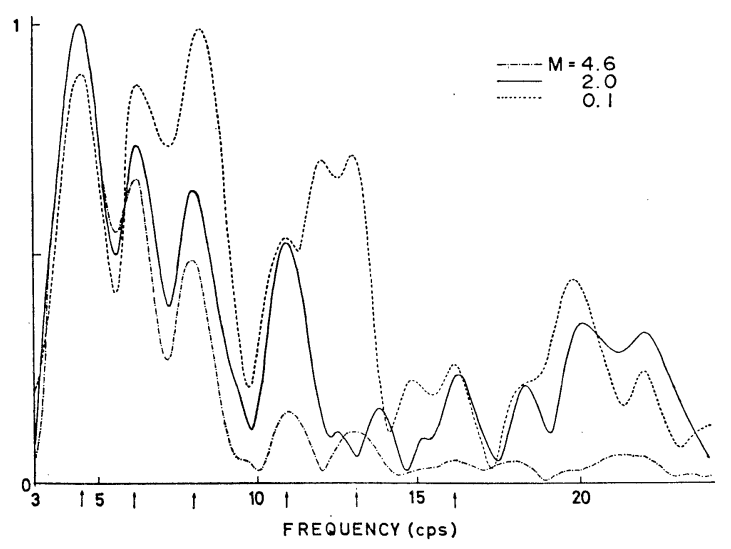

Fig. 7. Comparison of $\mathrm{P}$ wave velocity spectra of three events with different magnitude; the amplitude is normalized by the maximum value in each shock. The decrease in high frequency components with increasing magnitude is clearly seen. The peak positions at the frequencies indicated by arrows are common in the spectra of all events and are used to estimate the source model and $Q$ value (see Fig. 8).

MOGI (1967) や ScHOLZ (1968) は岩

石破壞実験を試みている.SCHOLZ の実験結果によると媒質の breaking stress に相対的に内 在する stress が高いほど $b$ 值は小さくなる。この結果を直接適用すると Earthquake family の存在する場は相対的な stress の高い状態にあることになる。この family の発生場所が 5 月 16 日の本震の余震域の一番西端でこれより外側では余震は 1 個も発生していないこと拉よ び No. 8 の本震後の余震の $b$ 值も変化のないこと等を説明するのに必ずしも都合が良くない. 一方 MOGI の解釈は地震の発生する媒質の heterogeneity や構造の nonuniformity の度合と ともに $b$ 值が増加するとするものである。この解釈からすれば今回の地震群はより uniform な構造の場所に発生したものと理解される。そしてこの結果は前述のように Earthquake family の地震は互に空間的，力学的共有部分が大きいとする立場と定性的に一致する.

従来の $b$ 值の研究は地震の集合を余震とかある地域内の地震など既製の分類法に依存してき た。この節では新しい観察に基く分類によつて $b$ 值の意味を解釈する手掛りをつかもらとする 試みを述べた。 

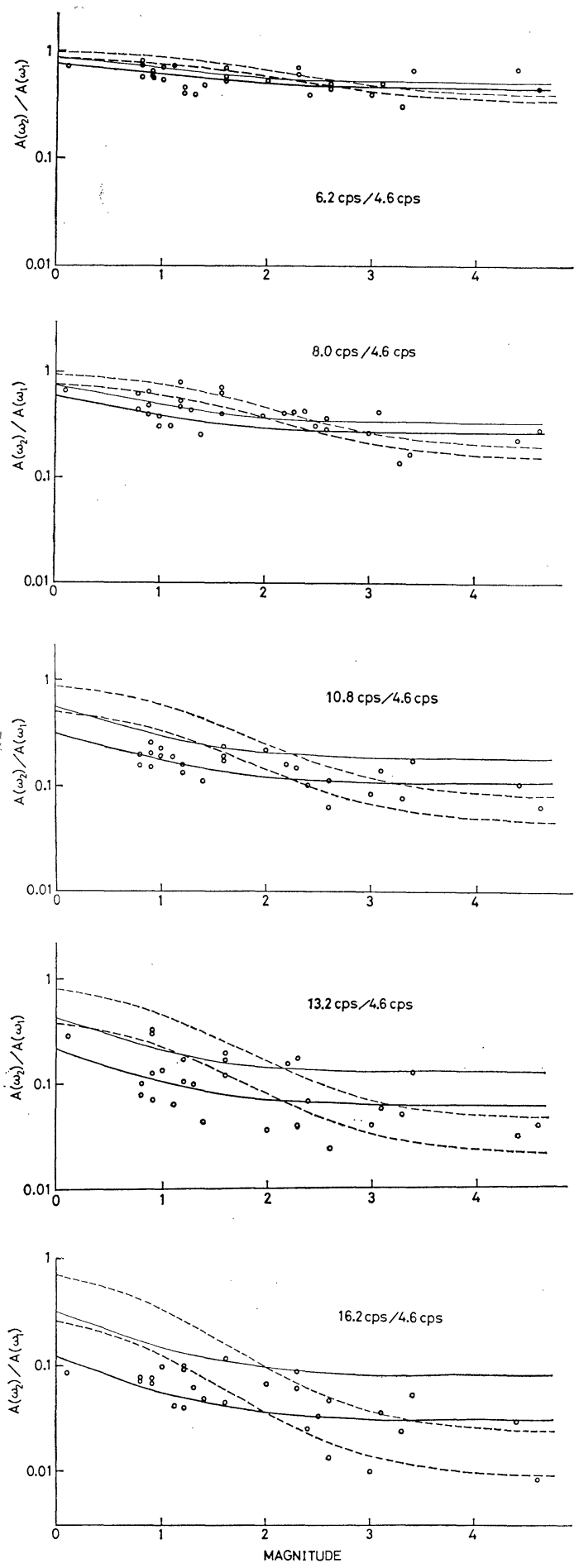

\section{§6. P 波スペクトルと $Q$}

波形の良く似ている Earthquake family のスペクトル構造は $M$ によつ てどのように変化しているであろらか。 測定場所や記録計の特性は一定であり また震源や発震機構は同一であると見 なして良い，従つて伝播径路での減衰 や構造による影響はすべて一定である との仮定がゆるされよう。dynamic range を広くとつているため波形歪み なく記録がとられている：この節では $\mathrm{P}$ 波初動部分のスペクトルを論ずる.

$140 \mathrm{~cm} / \mathrm{sec}$ 送りのオッシログラフ 上で初動より 0.4 秒までをサンプル間 隔 0.0075 秒で読取つたデータについ てフーリエ解析を扮こなつた. Fig. 7 にその例として $M$ の異なる三つの場 合を示した。この図では測定器の特性 の補正をおこなつたものについてスぺ クトルの最大値で規格化した速度振幅 スペクトルが示されている，スペクト ルの型は当然のことながら互にまつた く良く似ていること，又 $M$ が大きく

Fig. 8. Observed spectral amplitude ratio (open circle) at two frequencies of $f_{1}$ and $f_{2}$ against earthquake magnitude, $f_{2} / f_{1}$ being shown in the figure. Thin solid and broken lines indicate the theoretical curves of $\omega^{2}-$ and $\omega^{3}$-model respectively. Thick lines are the best fit to the observed data. The difference of the spectral amplitude ratio between two curves can be used to estimate $Q$ value (see Fig. 9). 
なるに従つて高周波成分が相対的に減 少していること, 执よびスペクトルの ピークの位置が $M$ の変化にもかかわ らず変つてないことがわかる. 図中で 矢印を附した $4.6,6.2,8.0,10.8$ ， 13.2 和よび $16.2 \mathrm{~Hz}$ のピークは殆ん どの地震に現われている。これらのピ ークでの振幅がマグニチュードに応じ てどのように変化しているかを見るた めに上記の各周波数でのスペクトル比 を縦軸に， $M$ を横軸にとり示したも のが Fig. 8 の白丸である. 但しこの 際速度振幅スペクトルは変位振幅に変 換されている. 図の (a)，(b)，(c)，(d)， (e) はそれぞれ $4.6 \mathrm{~Hz}$ に対する6.2， $8.0,10.8,13.2,16.2 \mathrm{~Hz}$ の変位ス ペクトル振幅比である.

今震源でのスペクトルを $S(\omega)$, 境 界での反射屈折による crustal response $C(\omega)$, instrumental response を $I(\omega)$, 観測されるスペクト

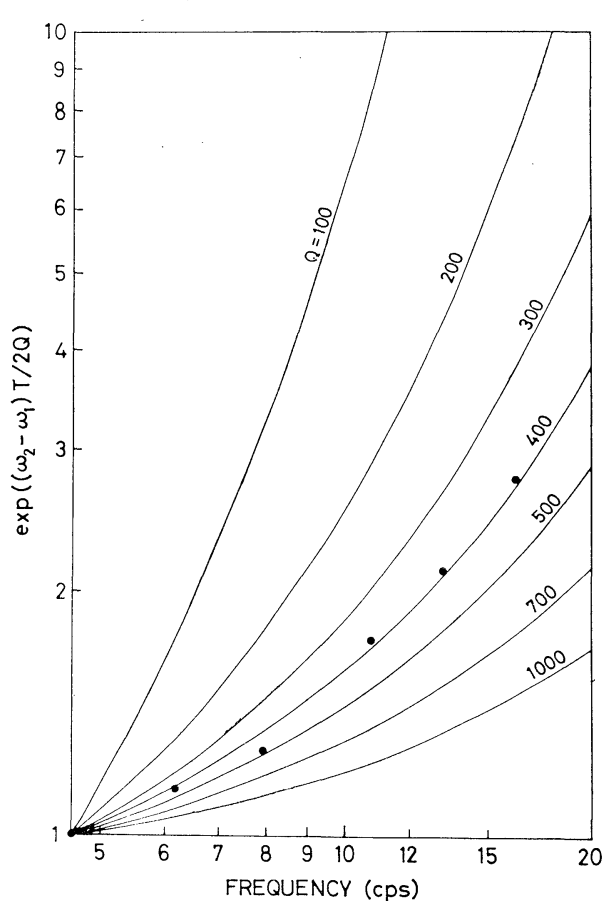

Fig. 9. The difference between the observed spectral amplitude ratio and the theoretical one is plotted against the frequency $f_{2}$ (solid circle). The curves are calculation of $\exp \left(\left(\omega_{2}-\omega_{1}\right) T / 2 Q\right)$ for various values of $Q$, where $\omega_{1}=2 \pi \times 4.6, \omega_{2}=2 \pi f_{2}$ and $T$ is travel time in seconds. The observed data agree well with the curve with $Q=400$. ルを $O(\omega)$ とすれば

$$
O(\omega)=k \cdot S(\omega) \cdot C(\omega) \cdot I(\omega) \cdot \exp (-\omega T / 2 Q)
$$

の関係で結ばれる。但し $T$ は観測点までの走時， $\omega$ は角周波数， $Q$ は波線に沿う平均の dissipation facter, $k$ は定数とする. 従つてある二つの角周波数 $\omega_{1}, \omega_{2}$ でのスペクトル振幅 比は

$$
\frac{O\left(\omega_{2}\right)}{O\left(\omega_{1}\right)}=\frac{S\left(\omega_{2}\right)}{S\left(\omega_{1}\right)} \cdot \frac{C\left(\omega_{2}\right)}{C\left(\omega_{1}\right)} \cdot \frac{I\left(\omega_{2}\right)}{I\left(\omega_{1}\right)} \cdot \exp \left(\left(\omega_{1}-\omega_{2}\right) T / 2 Q\right)
$$

となる. $I\left(\omega_{2}\right) / I\left(\omega_{1}\right)$ は instrumental response より既知の量である。 $C\left(\omega_{2}\right) / C\left(\omega_{1}\right)$ は厳密に は未知の量であるが考えている周波数帯域がそれほど広くないことや $\mathrm{P}$ 波初動から 0.4 秒間と いう短い時間帯を解析しているためここでは 1 と仮定する. 残る量は $S\left(\omega_{2}\right) / S\left(\omega_{1}\right)$ と $Q$ を含 
む exponential の項である. しかし後者の $Q$ の寄与は $M$ に無関係であり Fig. 8 において スペクトル比を縦軸に平行移動させるのみで横軸方向すなわち $M$ による変化は全て $S\left(\omega_{2}\right)$ / $S\left(\omega_{1}\right)$ の変化によると考えてよい，従つて $S(\omega)$ の比と $Q$ の寄与を分離させて調べることが 出来る.

さて震源スペクトルの理論模型としては $\omega^{3}$-model [HASKELL (1966), AKI (1967)] と $\omega^{2}-$ model [AKI (1967)] がある. AKI の定義式にしたがえば震源での変位スペクトル密度 $A(\omega)$ は $\omega^{3}$-model のとき

$$
A(\omega)=D_{m} /\left(1+\omega^{2} / k_{T}^{2}\right)^{3 / 2},
$$

また $\omega^{2}$-model のとき

$$
A(\omega)=D_{m} /\left(1+\omega^{2} / k_{T}{ }^{2}\right)
$$

で与えられる. 但し $D_{m}=w D_{0} L, \cos \theta=0, v k_{L}=k_{T}$ とする， $D_{m}, k_{T}$ は $\omega$ に関して一定で あるが $M$ の関数である. 従つてある $M$ の地震の二つの角周波数 $\omega_{1}, \omega_{2}$ でのスペクトル比 は $M$ の関数として, $\omega^{3}$-model の場合

$$
\frac{A\left(\omega_{2}\right)}{A\left(\omega_{1}\right)}=\left(\frac{k_{T}{ }^{2}+\omega_{1}^{2}}{k_{T}^{2}+\omega_{2}{ }^{2}}\right)^{3 / 2},
$$

また $\omega^{2}$-model の場合

$$
\frac{A\left(\omega_{2}\right)}{A\left(\omega_{1}\right)}=\left(\frac{k_{T}^{2}+\omega_{1}^{2}}{k_{T}^{2}+\omega_{2}^{2}}\right)
$$

となる. Table 1 に使用した $M$ は $M_{\mathrm{JMA}}$ に対応するよう決められたものである。 また $M_{\mathrm{JMA}}$ は $M_{s}$ 系と考吕られるから結局近似的に $M$ は $M_{s}$ に相等するものであるとして AKI (1967) の $k_{T}$ の值をそのま使用する．Fig. 8 の細い実線は $\omega^{2}$-model に，細い破線は $\omega^{3}$-model に対応する理論スペクトル比である。この曲線と観測值を比較する場合まだ $Q$ の影響を考慮 に入れていないためスペクトル比の絶対值は考えないで $M$ による変化の傾向のみ着目する. $\omega^{3}-$ と $\omega^{2}$-model と観測值を比較するとバラッキはあるが $\omega^{2}$-model が観測值に良く合つて いるように見える。データのバラッキに関しては今扱つている周波数領域を考慮すればむしろ 短周期のわりに理論曲線と一致していると見るべきであろう.

このままでは観測值と理論值の間にまだ減衰の影響が残つている。そこで観測值に最も合う ように理論曲線を綎軸に平行移動させる。 その結果を $\omega^{2}$-model と $\omega^{3}$-model に対してそれ ぞれ太い実線および点線で示した。この時の移動量の逆数を縱軸に周波数を横軸にプロットし たものが Fig. 9 の黒丸である。 またこの図の曲線は $\exp \left(\left(\omega_{2}-\omega_{1}\right) T / 2 Q\right)$ を $\omega_{1}=2 \pi \times 4.6 \mathrm{~Hz}$ を基準として， $Q$ をパラメーターにして描いたものである．両者の比較より $Q=400$ の曲線 
が良く一致していることが読みとれる。

観測点までの地震波線はこの地方の地殼構造から推定すれば最深点を $6.6 \mathrm{~km} / \mathrm{sec}$ 層にもつ 地殼内に限られる。 また波線の通過する地殼はいわゆる dipping seismic zone がもぐりはじ める位置の上部にあたり微小地震観測からは aseismic な地域 [HAMAGUCHI et al. (1973)] になつている.

\section{§7. 結 論}

1) 1968 年十勝沖地震の観測された約 5 万個の余震の中より 72 個におよぶ相似な波形を もつ地震群を見出した。

2)このような波形の相似な地震群を地震の集合の基本的単位と考光 Earthquake family と呼ぶ.この Earthquake family の出現は約 80 日間に渡つている.この間の波形の対応性 （相似性）は $M$ が $1.0 \sim 4.6$ の広い範囲にわたつて非常に良い。 また $M$ の減少と共に高周 波成分の卓越してくることが明瞭に読みとれる.

3） $M$ がほ涪等しい地震に限れば初動より後続波の細部に至るまで相似性は非常に良い.

4）以上の事実は震源での波動生成機構が単純なものであることを示唆している.

5)この Earthquake family の内比較的大きい地震の震源分布からするとこの地震群はほ ぼ同一の場所（ $\pm 5 \mathrm{~km}$ 以内）に発生し互の地震は空間的また力学的な性質の共有部分が大き い可能性がある. この地震群の震央は十勝沖地震の余震域の外輪に位置している.

6) Earthquake family の発生様式は基本的には群発型であるが, 細かく見れば前震一本 震一余震型の合成とも考学られる.

7) Earthquake family の $b$ 值は $0.43(N=68)$ と異常に小さい值をもつ.この結果は SCHOLZ よりも MOGI の解釈と調和的である.

8） P 波部分のスペクトル解析より source model としては $\omega^{2}$-model が 4.6 から 16.2 $\mathrm{Hz}$ の周波数領域で観測と良く合う。また理論 model との比較よりこの地域の地殼の平均的 な值として $Q_{\alpha}=400$ を得た。

余震観測およびデータ整理の際には笠原 稔氏 (現在北海道大学理学部えりも地殼変動観測 所）の協力を得た. 北海道大学理学部浦河地震観測所の本谷義信氏には験震表にない小さい地 震をで読取つて頂いた。 また北海道大学理学部地球物理学教室の岡田 弘氏より恵山臨時観測 点のデータの提供をうけた。東北地方の各測候所からは仙台管区気象台を通じて原記録ないし 読取り原簿よりデータの提供をうけた。東北大学微小地震観測網のデータは原記録より読取り 
させていただいた，関係の皆様方に厚く感謝致します。

鈴木次郎教授, 高木章雄教授の終始変らざる御指導に感謝致します.

データ処理は東北大学大型計算機センターで行つた.

\section{文献}

AKI, K., 1965, A Computer Program for Precise Determination of Focal Mechanism of Local Earthquakes by Revising Focal Depth and Crust-Mantle Structure, Bull. Earthq. Res. Inst., Tokyo Univ., 41, 615-658.

AKI, K., 1967, Scaling Law of Seismic Spectrum, J. Geophys. Res., 72, 1217-1231.

Berckhemer, H., 1962, Die Ausdehnung der Bruchfläche im Erdbebenherd und Ihr Einflu $\beta$ auf das Seismiche Wellenspectrum, Gerlands Beitr. Geophys., 71, 5-26.

Duennebier, F. and G. H. Sutton, 1974, Thermal Moonquakes, J. Geophys. Res., 79, 43514363.

Hamaguchi, H. and A. HaSegawa, 1970, An Investigation on the Aftershocks of the Tokachi-Oki Earthquake of 1968, (1) Statistical Study on Magnitude Distribution, Sci. Rep. Tôhoku Univ., Ser. 5, Geophys., 20, 85-105.

Hamaguchi, H., H. Watanabe, K. Takano, F. J. Gumper and G. Boucher, 1973, Microearthquake Survey in Northeastern Honshu, Japan, J. Phys. Earth, 21, 1-18.

HASKell, N., 1966, Total Energy and Energy Spectral Density of Elastic Wave Radiation from Propagating Faults. Part II. A Statistical Source Model, Bull. Seism. Soc. Amer., 56, $125-140$.

松沢武雄, 1933, 地震, p. 77-80, 岩波書店.

McEvilly, T. V. and K. B. CASADAY, 1967, The Earthquake Sequence of September, 1965 Near Antioch, California, Bull. Seism. Soc. Amer., 57, 113-124.

Miyamura, S., S. Омотe, R. Teisseyre and E. Vesanen, 1965, Multiple Shocks and Earthquake Series Pattern, Bull. Inter. Inst. Earthq. Eng., 2, 71-92.

MogI, K., 1963, Some Discussions on Aftershocks, Foreshocks, and Earthquake Swarms-the Fracture of a Semi-Infinite Body Caused by an Inner Stress Origin and Its Relation to Earthquake Phenomena, 3, Bull. Earthq. Res. Inst., Tokyo Univ., 41, 615-658.

MogI, K., 1967, Earthquakes and Fractures, Tectonophysics, 5, 35-55.

村松郁栄, 1964, Magnitude の定義式について, 地震 $2,17,210-221$.

村松郁栄, 1966, Magnitude の式の訂正抢よび注釈, 地震 2, 19, 282-285.

OIKE, K., 1969, The Deep Earthquake of June 22, 1966 in Banda Sea: A Multiple Shock, Bull. Disas. Prev. Res. Inst., Kyoto Univ., 19, Part 2, 55-65.

OMORI, F., 1905, Horizontal Pendulum Observations of Earthquakes in Tokyo: Similarity of the Seismic Motion Originating at Neighbouring Centres, Publ. Earthq. Invest. Commit., 21, 9-102.

OMoRI, F., 1919, The Eruptions and Earthquakes of the Asamayama, VI, Notes on the Eruptive and Seismic Disturbances, 1911-1917, Bull. Imp. Earthq. Commit., 7, 327-416.

ReSEARCH Group For Aftershocks, 1971, General Description of the Special Observations in Case of the Tokachi-Oki Earthquake of 1968, in General Report on the Tokachi-Oki Earthquake of 1968 (ed. Z. SuzukI), Keigaku Pub. Co., 85-114.

Scholz, C. H., 1968, The Frequency-Magnitude Relation of Microfracturing in Rock and its Relation to Earthquakes, Bull. Seism. Soc. Amer., 58, 399-415.

Stauder, W. and A. RYall, 1967, Spatial Distribution and Source Mechanism of Microearthquakes in Central Nevada, Bull. Seism. Soc. Amer., 57, 1317-1345.

SuYeHiRo, S., T. ASADA and M. OHTAKE, 1964, Foreshocks and Aftershocks Accompanying a Perceptible Earthquake in Central Japan-On the Peculiar Nature of Foreshocks-, Papers Met. Geophys., 14, 71-88.

SuYeHIRo, S., 1969, Difference in the Relationship of Magnitude to Frequency of Occurrence 
between Aftershocks and Foreshocks for an Earthquake of Magnitude 5.1 in Central Japan, Papers Met. Geophys., 20, 175-187.

SuzukI, Z., 1953, A Statistical Study on the Occurrence of Small Earthquakes, I, Sci. Rep. Tôhoku Univ., Ser. 5, Geophys., 5, 177-182.

SuzukI, Z., 1959, A Statistical Study on the Occurrence of Small Earthquakes (fourth paper), Sci. Rep. Tôhoku Univ., Ser. 5, Geophys., 11, 10-54.

Tsujiura, M., 1973, Spectrum of Seismic Waves and Its Dependence on Magnitude (1), J. Phys. Earth, 21, 373-391.

Utsu, T., 1969, Aftershocks and Earthquake Statistics (I)-Some Parameters Which Characterize an Aftershock Sequence and Their Interrelations-, J. Fac. Sci., Hokkaido Univ., Ser. VII, 3, 129-195.

UTSU, T., 1970, Aftershocks and Earthquake Statistics (II)-Further Investigation of Aftershocks and Other Earthquake Sequences Based on a New Classification of Earthquake Sequence-, J. Fac. Sci., Hokkaido Univ., Ser. VII, 3, 197-266.

UTSU, T., 1971, Aftershocks and Earthquake Statistics (III)-Analyses of the Distribution of Earthquakes in Magnitude, Time, and Space with Special Consideration to Clustering Characteristics of Earthquake Occurrence (1)-, J. Fac. Sci., Hokkaido Univ., Ser. VII, 3, 379-441. 